\title{
Rainbow Smart Parking System Design: Problems Into Solutions for Integrated Parking Management
}

\author{
M. Rooshihan ${ }^{1}$, M.S. Che Rusuli ${ }^{1}$, A.K. Suhaila ${ }^{1}$, M. Hakim ${ }^{1}$, R. Ashlyzan ${ }^{1}$ \& W.M.N. Mohd Nazdrol ${ }^{1}$ \\ ${ }^{1}$ Universiti Malaysia Kelantan, Malaysia \\ Correspondence: M.S. Che Rusuli, Universiti Malaysia Kelantan, Malaysia.
}

Received: May 1, 2019

Accepted: June 1, 2019

Online Published: July 8, 2019

doi:10.5430/rwe.v10n2p66

URL: https://doi.org/10.5430/rwe.v10n2p66

\begin{abstract}
This paper scrutinize the crucial problems such as insufficient parking space, road design, behavior of parking and peak time parking as a major factor that contribute to the improperness of car parking management. This study involves 250 respondents which took place at Pengkalan Chepa neighborhood. The sample adopts convenient sampling methods. Furthermore, this study promotes the idea to solve the incapacity of parking facilities around Pengkalan Chepa. As the result, several solutions were proposed to both university members and local community and authority to look further in this matter.
\end{abstract}

Keywords: campus, transportation, university, parking, Malaysia

\section{Introduction}

The increasing number of cars as mode of transportation has affects the parking facilities regardless of how well this issue was taken care of. This problematic issue also occurs at most of university campuses in Malaysia. University campus can be defined as a small "smart city" due to their own communities comprising of students, lecturers and other staffs blends in their own daily ecosystem within the university's own infrastructure i.e. roadway, water supply, electrical supply, sewerage system and others (Norzalwi and Ismail, 2011). Modern university campuses have been designed as pedestrian friendly which requires less transportation within the campus. Despite that, the local culture stills a big influence which encourages most of university's community to drive their own transport at every opportunity. (Malakiya, Gothi, Mehta, Shaikh \& Dave, 2016; Aalsalem \& Khan, 2016). This phenomenon was observed as a reflection to a major city with a similar problem (Danilina \& Slepnev, 2018; Norzalwi and Ismail, 2011). Therefore, more pressure lay on campus management to increase parking lots as well as the size and number of roadways (Kaplan, 2015; Myambo \& Munyanyi 2017). To date, this study focus on identifying causes on the inappropriate of car park management at the campus and addressing solution to alleviate the problem. The objectives of this study are:

a) To identify the determinant factors (i.e. insufficient parking space, road design, parking behavior and peak time parking) that causing the improperness of carpark management in UMK.

b) To analyze the effective ways to overcome the improperness of carpark management in UMK.

c) To develop the solutions as to solve the problem of the improperness of carpark management in UMK.

\section{Literature Review}

To date, public parking space is one of the significant modern urban transportation systems, which acts in reducing heavy traffic load (Taylor et al., 2011; Myeni \& Mvuyana 2018). The insufficient parking facilities causes a major bottleneck in the traffic smooth flow, due to the vehicles are parked on the street side (Batabyal \& Nijkamp, 2010). The insufficient parking space is resulted by the fact of parking is free and on-street parking is unregulated. Hence, precious road spaces are taken up by parked vehicles and leave less road space for moving vehicles (Rajashekara et al., 2014). Parking spaces are either inadequate due to high students' demand or poorly allocated of these spaces (Shinde et al., 2015; Myambo \& Munyanyi 2017).

Parking facilities design and operation is known as physical layout, day-to-day management and construction. By improving the design and operation it could bring better parking facilities into society, address specific problems, enhance service quality and enforce parking management as well (Litman, 2013). Previous study done by Ede et al. 
(2015) and Tembhurkar and Khobragade (2015) found that the land design or layout can influence the choice of travel mode. It means that the proper use of land will influence the appearance, traffic levels and congestion points when societies plan for the future in university.

The management of parking are referring to the type of policies and programs in term of the parking spaces are used efficiency. The parking spaces are also play an important role in term of people who want to leave their vehicles for a certain time. Parking facilities are a major cost to society, and parking conflicts are among the most common problems (Litman, 2013; Nkiru, Sidi \& Abomeh 2018). The conflicts here are referring to consumer attitudes, which is not easy to manage because their behaviour is change follow by the current situation. The attitude that mention here is consumer take two lots parking for their car, did not parking properly and double parking.

Previous study done by Shoup (2005) and Roth (2004) revealed that university parking problems constitute a special case. It explains why this particular issue has escaped much of the recent literature of the economics of parking. This situation happens whereby most people will go out like a student will come to campus to attend a class, lecturers and staffs are having their own business. A common complaint related to the university parking monopoly regards a perceived lack of enforcement of existing rules (Schmidt \& Westley, 2010; Nurulhuda, Hasan \& Mohd 2018). This is because of the demand for parking exceed than daily usage.

\section{Methodology}

The quantitative method and a non-probability convenience sampling was chosen for the sampling design as there is no specific list of respondent that can be established from the population in the sampling frame. Through convenience sampling, a total number of 4302 population will randomly selected. This sampling technique eases the researcher's works in collecting the responses. For the sample size, 280 respondents was equal choose as to achieve the reliable result. However, only $89 \%$ of respondents was answer the question. For validity and realibility of questionnaire, Cronbach alpha value is 0.873 which indicates that it is a good association and acceptable in this study.

\section{Results}

The significant levels of both variables are 0.000 that demonstrate significant. The correlation coefficient for insufficient parking spaces and improperness of car park management is 0.532 . This indicates the two variables were correlated and has a positive relationship, which is positive high correlation. Hence, this result demonstrated that insufficient parking spaces is one of the major factors that impacting the improperness of car park management in UMK campus. Based on Barata, Cruz \& Ferreira (2010), the insufficient parking spaces (Danilina \& Slepnev, 2018; Boussauw \& Vanin, 2018) and poor control over non regular parking at the campus, have boosted these difficulties, especially the campus is overcrowded and underpriced. This statements support that problem of improperness of car park management is caused by shortage of parking spaces. Researchers have accepted that insufficient parking spaces have a significant relationship with improperness of car park management.

The significant levels of both variables are 0.000 that demonstrate significant. The correlation coefficient for road designs and improperness of car park management is 0.648 . This indicates the two variables were correlated and has a positive relationship, which is positive high correlation. Hence, this result demonstrated that road designs is one of the major factors that impacting the improperness of car park management in UMK campus. According to Yorgri, Wen \& Hong (2016), the car parks' designs and construction can ease or cause improperness of car park management especially within Ghana with an insufficient or narrow road infrastructure. This statements support that problem of improperness of car park management is caused by road designs. Researchers have accepted that road designs have a significant relationship with improperness of car park management.

The significant levels of both variables are 0.000 that demonstrate moderate significant. The correlation coefficient for behavior of parking and improperness of car park management is 0.541 . This indicates the two variables were correlated and has a positive relationship, which is positive high correlation. Hence, this result demonstrated that behavior of parking is one of the major factors that impacting the improperness of car park management in UMK campus. According to Simićević, et al. (2012), some of the car drivers eventually park illegally on the streets have additionally contributed to parking lots problems. This statements support that problem of improperness of car park management is caused by behavior of parking. Researchers have accepted that behavior of parking have a significant relationship with improperness of car park management.

The significant levels of both variables are 0.000 that demonstrate significant. The correlation coefficient for peak time parking and improperness of car park management is 0.621. This indicates the two variables were correlated and has a positive relationship, which is positive high correlation. Hence, this result demonstrated that peak time 
parking is one of the major factors that impacting the improperness of car park management in UMK campus. Based on Litman (2013), during peak periods, more than $90 \%$ rates of public garages were only half occupied and never totally full virtually by the reasons of the lack of integration between off- and on-street parking. This statements support that problem of improperness of car park management is caused by peak time parking. As such, this study accepted that peak time parking has a significant relationship with improperness of car park management.

Furthermore, the reliability value for all variables is good $(0.7<0.913<0.9)$. Besides, the significance values for all four (4) variables are 0.000 . This result indicates that all the independent variables were examined, that is, Insufficient Parking Spaces, Road Design, Behavior of Parking and Peak Time Parking contribute a significant relationship to the Improperness of Car Park Management in Universiti Malaysia Kelantan. Hence, these results have answered the hypotheses formulate in this research. Besides, the factor that most affect the improperness of car park management in campus is Road Design, by the reason of the factor showed the smallest p-value among the four independent variables. Simultaneously, the Peak Time Parking is the second factor whereas the Behavior of Parking is the third factor that the response variable. Last but not least, the insufficient parking space is the fourth factor that impacts the improperness of car park management in campus.

\section{Conclusion}

In conclusion, the implementation of colors stratification parking system is significantly influenced by improperness car park management in campus, insufficient parking space, road design, behavior of parking and peak time parking factors. By examining past researchers' study, the problems are more focusing on the ineffective parking management at campus that causes others problems existed. Furthermore,, this study need to be determine the potential system that could be influence the willingness to implementing colors stratification parking system and reformulation parking lots for car park management.

\section{Acknowledgement}

This research is supported by the SGJP research grant No. R/SGJP/A01.00/01425A/001/2016/000326 from Research, Innovation, Management, and Commercialization (RMIC), University Malaysia Kelantan (UMK). We also would like to express our gratitude to all researchers for their cooperation in this study.

\section{References}

Aalsalem, M. Y., \& Khan, W. Z. (2016). CampusSense-A Smart Vehicle Parking Monitoring and Management System using ANPR Cameras and Android Phones. 2017 19th International Conference on Advanced Communication Technology (ICACT). https://doi.org/10.23919/ICACT.2017.7890230

Abdul Malek, A. A. (2012). A study of parking problems in Muar town. Case study: Street on Muar town (Jalan Salleh). Student Project. Faculty of Architecture, Planning and Surveying, Shah Alam.

Barata, E., Cruz, L., \& Ferreira, J. P. (2010). Parking Problems at the UC Campus: Setting the Research Agenda. Paper presented at the 12th World Conference on Transport Research Society (WCTRS), Lisbon, Portugal.

Batabyal, A. A., \& Nijkamp, P. (2010). A probabilistic analysis of two university parking issues. The Annals of Regional Science, 44(1), 111-120. https://doi.org/10.1007/s00168-008-0237-8

Boussauw, K., \& Vanin, F. (2018). Constrained sustainable urban mobility: the possible contribution of research by design in two Palestinian cities. Urban Design International, 1-18. https://doi.org/10.1057/s41289-018-0059-y

Danilina, N., \& Slepnev, M. (2018). Managing smart-city transportation planning of "Park-and-ride" system: case of Moscow metropolitan. Paper presented at the IOP Conference Series: Materials Science and Engineering. https://doi.org/10.1088/1757-899X/365/2/022002

Ede, A. N., Adaramola, O., \& Olofinnade, O. M. (2015). Modelling, Analysis and Design of a Multi-Storey Helipad-Car Park: a Proposal for Canaan Land. International Journal of Innovative Science and Modern Engineering, 3(4), 43-47.

Kaplan, D. H. (2015). Transportation sustainability on a university campus. International Journal of Sustainability in Higher Education, 16(2), 173-186. https://doi.org/10.1108/IJSHE-03-2013-0023

Litman T. (2013). Parking Management Strategies, Evaluation and Planning. Victoria Transport Policy Institute.

Malakiya, K., Goti, J., Mehta, M., Shaikh, Z., \& Dave, K. (2016). Survey Paper on the Parking Management. Global Journal for Research Analysis, 5(4), 264-266. 
Myambo, A., \& Munyanyi, T. (2017). Effecetiveness of Labour Court in Labour Dispute Management in Zimbabwe. International Journal of Social and Administrative Sciences, 2(1), 15-30. https://doi.org/10.18488/journal.136.2017.21.15.30

Myambo, A., \& Munyanyi, T. (2017). Fiscal Operations and Macroeconomic Growth: The Nigerian Experience. International Journal of Social and Administrative Sciences, 2(1), 31-44. https://doi.org/10.18488/journal.136.2017.21.31.44

Myeni, S. L., \& Mvuyana, B. Y. (2018). Participatory Processes in Planning for Self-Help Housing Provision in South Africa: Policies and Challenges. International Journal of Public Policy and Administration Research, $5(1), 24-36$.

Nkiru, N., Sidi, C. P., \& Abomeh, S. (2018). Impact of Information and Communication Technology on the Performance of Deposit Money Banks in Nigeria. International Journal of Management, 7(4), 225-239. https://doi.org/10.18488/journal.11.2018.74.225.239

Norzalwi, N., \& Ismail, A. (2011). Public approach towards sustainable transportation in UKM's campus. Australian Journal of Basic and Applied Sciences, 5(5), 1332-1337.

Nurulhuda, S., Hasan, R., \& Mohd, A. (2018). Does Gold Price Lead or Lags Islamic Stock Market and Strategy Commodity Price? A Study from Malaysia. International Journal of Business, 5(6), 146-163. https://doi.org/10.18488/journal.62.2018.56.146.163

Rajashekara, M. R., Khan, M. K., \& Kattimani, R. R. (2014), Appraisal of Multilevel Car Parking Facility at Kg Road-Cbd Area, Bengaluru. IJRET: International Journal of Research in Engineering and Technology, 3(8), 76-91. https://doi.org/10.15623/ijret.2014.0308014

Roth, G. (2004). An Investigation into Rational Pricing for Curbside Parking. Doctoral dissertation, Columbia University.

Schmidt, B. H., \& Westley, C. (2010). The University-as-Monopolist: Why Parking Problems Persist at University Campuses. The Journal of Applied Business and Economics, 10(6),

Shinde Smita, N., Shinde Komal, V., Nagpure Rashmila, D., Tupkar Avanti, S., \& Ankoshe, M. S. (2015). An Android Application for Parking Management and Dissemination System. International Journal of Advanced Research in Computer Engineering \& Technology (IJARCET), 4(3), 1075-1080.

Shoup, D. (2005). The High Cost of Free Parking, Edited by A. P. Association. Chicago: Planners Press.

Simićević, J., Milosavljević, N., \& Maletić, G. (2012). Influence of Parking Price on Parking Garage Users' Behaviour. PROMET-Traffic \& Transportation, 24(5), 413-423. https://doi.org/10.7307/ptt.v24i5.1177

Taylor, B. T., Fernando, P., Bauman, A. E., Williamson, A., Craig, J. C., \& Redman, S. (2011). Measuring the quality of public open space using Google Earth. American Journal of Preventive Medicine, 40(2), 105-112. https://doi.org/10.1016/j.amepre.2010.10.024

Tembhurkar, A., \& Khobragade, P. (2015). Parking Demand Forecast Model for Institutional Campus. Proceedings of International Conference on Transportation and Civil Engineering (ICTCE'15) London, March 21-22, 39-42.

Yorgri, E., Wen, C., \& Hong, L. (2016). Parking Planning and Policy in the CBD of Accra. Ghana. International Journal of Advances in Agricultural \& Environmental Engineering, 3(2), 300-304. https://doi.org/10.15242/IJAAEE.U0616305 